\title{
An Investigation of Corporate Sustainability Value to Investors Before and After the Financial Crisis
}

\author{
Rudolf B. Baas ${ }^{1}$, Georgios Georgakopoulos ${ }^{2}$, Konstantinos Z. Vasileiou ${ }^{3} \&$ Ioannis Sotiropoulos $^{4}$ \\ ${ }^{1}$ Amsterdam Business School, University of Amsterdam, Netherlands \\ ${ }^{2}$ Department of Accounting \& Finance, University of Strathclyde, UK \\ 3 Department of Business Administration (Patras), Technological Educational Institute of Western Greece, \\ Greece \\ ${ }^{4}$ Department of Accounting \& Finance, TEI of Epirus, Greece \\ Correspondence: Konstantinos Z. Vasileiou, Department of Business Administration (Patras), Technological \\ Educational Institute of Western Greece, Greece. E-mail: vasileiou@ teipat.gr
}

Received: February 17, 2016

Accepted: April 21, 2016

Online Published: May 25, 2016

doi:10.5539/ijef.v8n6p37

URL: http://dx.doi.org/10.5539/ijef.v8n6p37

\begin{abstract}
During the last decennia there is a shift in corporate sustainability strategies amongst large companies, as they increasingly exhibit an inclination to opt to strategies which do not aim solely on the maximization of shareholders value, but they consider, as well, environmental and social aspects. This paper investigates the impact on the share price of the companies included in or excluded from the Dow Jones Sustainability World Index before (2006-2007) and after (2009-2010) the financial crisis, employing the CAPM-model. The research results reveal that after the financial crisis the investors changed their investment strategies in favor of the more corporate sustainable companies (included in the DJSWI) compared to unsustainable companies (excluded from the DJSWI). However, the exclusion of a company from the DJSWI was not found to have a significant negative impact on the companies' share price.
\end{abstract}

Keywords: corporate sustainability, Dow Jones Sustainability World Index, CAPM-model, financial crisis, share price

\section{Introduction}

Corporate sustainability reports are defined as "public reports by companies to provide internal and external stakeholders with a picture of the corporate position and activities on economic, environmental and social dimensions" (WBCSD, 2002). This definition emphasizes the necessity for companies to report on economic, environmental, and social aspects of sustainability. The motivations for corporate sustainability reporting include, inter alia, enhanced ability to track progress against specific targets, greater awareness of broad environmental issues, improved all-round credibility from greater transparency, and reputational benefits (Kolk, 2010). There is an increasing interest in using the information in sustainability reports to guide investment decisions. However, investors require information that goes beyond the information within the corporate sustainability reports. Therefore, indices linked to financial markets have emerged, including the Dow Jones Sustainability Index (DJSI) (Searcy et al., 2012). Lopez et al. (2007) mentioned the importance of companies to be listed in the Dow Jones Sustainability World Index (DJSWI) because it shows to investors that the company is long-term oriented and this could create a better long-term performance and therefore, long-term value creation.

Hoon et al. (2013) examined how firms from the financial sector are evaluated and rated via the DJSWI. They also introduced the term Social Responsible Investment (SRI), which refers to: "the practice of directing investment funds in ways that combine investors'financial objectives with their commitment to social concerns." Most major fund managers have introduced SRI funds, and in 2010 professionally managed assets based on SRI strategies had an estimated value of $\$ 3.07$ trillion. SRI funds have two different aspects: they may influence companies to change their behavior regarding sustainability and SRI funds' performance is not different from conventional investments in the short run, but it is likely to be superior in the long run. Companies that emphasize on Corporate Social Responsibility (CSR) will gain a competitive advantage and are likely to outperform their peers (Hoon et al. 2013). 
CSR practices (e.g. management quality, environmental management, brand reputation, customer loyalty, corporate ethics and talent retention) are becoming increasingly important for successful businesses (Lopez et. al., 2007). Measures included in the term CSR (adopting ethical codes, better environmental practices, or human capital development) are usually considered a good strategy which would lead to better performance. Thus, focusing on CSR practices and developing a strategy based on the term CSR would enable companies to attain long-term sustainable competitive advantages (Adams \& Zutshi, 2004; Lopez et al., 2007).

Robinson et al. (2011) investigated the impact on the share price of the companies included in or excluded from the DJSI for the period 2003-2007, before the emergence of the financial crisis. They found a significant increase in share prices when the company was included on the DJSI, but the share price did not decrease when the company was excluded from the DJSI. Lopatta et al. (2013) investigated the effect of the financial crisis on the valuation of corporate sustainability by utilizing the index of Global Engagement Services (GES) (the international rating agency) instead of the DJSI. They found a change in abnormal returns when a company is proven to be corporate sustainable after the financial crisis compared to before the financial crisis. However, companies that were no longer operating in a corporate sustainable manner did not realize a reduction in abnormal returns. Moreover, Lopatta et al. (2013) showed that the financial crisis in 2008 has led to a positive perception of corporate sustainability in industries that are exposed to higher environmental and social risks and therefore, such companies should increase their focus towards corporate sustainability. Additionally, Cheung (2011) investigated for the period 2002-2008 the effect of index (DJSWI) inclusions and exclusions on corporate sustainable firms. He did not find strong evidence that the announcement (of companies being included or excluded by RobecoSAM) has a significant impact on stock returns, but he did measure a temporary shock on the day of change.

According to the aforementioned literature it is evident that there is an increasing interest to investigate the impact on the companies' share prices which they changed their sustainability practices. Moreover, considering that the financial crisis in 2008 caused a shift in social responsible investments, this research aims to examine the relation between the inclusion or exclusion of a company on the Dow Jones Sustainability World Index and the share price of North American listed companies before and after the financial crisis.

The outline of the paper is structured as follow: Next section deals with the literature review with regard to the Dow Jones Sustainability Index, the Social Responsible Investments, the long-term value creation caused by corporate sustainability and lastly some theories relevant to the corporate sustainability. The research hypotheses, methodology and data sample are then presented, followed by our research results. The paper concludes with a discussion of our findings, limitations of our work and areas for future research.

\section{Literature Review}

\subsection{The Dow Jones Sustainability World Index}

The Dow Jones Sustainability World Index (DJSWI) was introduced in 1999, and at that time it was the first global sustainability benchmark (Hoon et al., 2013). The Dow Jones Sustainability Indexes (The Dow Jones Sustainability World Index, The Dow Jones STOXX Sustainability Index, The Dow Jones Sustainability Index North America and the Dow Jones Sustainability Asia Pacific Index) were established to track the performance of company leaders in the field of corporate sustainability (Searcy et al., 2012). The DJSWI tracks the performance of the top $10 \%$ of the 2,500 largest companies. The DJSWI uses information from annual surveys, annual reports, sustainability reports, media coverage, and other company documents to rate the CSR performance of those companies (Hoon et al., 2013).

The DJSWI is divided into 59 different industries (RobecoSAM, 2014). For each industry different weights are appointed to the different measures, which are divided in three different dimensions: economic, environmental and social. The emphasis (weight) on each dimension depends on the industry, which affects the total score among different industries. Each dimension has different criteria where the company can score points, with each criterion being assigned with a different weight. Examples of criteria are: antitrust policy, codes of conduct, corporate governance, customer relationship management, risk \& crisis management and tax strategy (economic dimension); climate strategy, environmental policy/management system, environmental reporting, operational eco-efficiency and product stewardship (environmental dimension); enabling local development, human capital development, labor practice indicators \& human rights, occupational health \& safety, social impacts on communities, stakeholder engagement and talent attraction \& retention (social dimension) (RobecoSAM, 2014).

Another important aspect of the DJSI assessment is the ongoing, on a daily basis, monitoring of media and stakeholder commentaries and other publicly available information. This includes host of issues such as corruption, fraud, human rights violation, workplace safety, labor disputes, catastrophic accidents and 
environmental disasters. If a company is accused of something that could harm its reputation, then this should react in order to minimize the potential negative impact on its image (Hoon et al., 2013). These effects are included in the DJSI assessment.

\subsection{Social Responsible Investments}

The DJSI is a widely used benchmark of social responsible investments (SRI). 'SRI' refers to the practice of managing investment funds in ways that combine investors' financial objectives and their commitment to social concerns (Hoon et al., 2013). Since the 90s social responsible investments have grown rapidly around the world. An important reason for this growth was the ethical consumerism, which means that consumers pay a premium for products that meet their personal values (Renneboog et al., 2008). Things like environmental protection and human rights have become important issues within the SRI investments. Another important factor for the growth of SRI are the changes in regulation regarding the disclosure of social responsible and sustainable practices for listed companies. Renneboog et al. (2008) mention that SRI investors aim to promoting strong social and environmental corporate behavior by selecting only companies with strong social and environmental records and with a good corporate governance, which is called 'positive screening'. Thus, SRI investors expect companies not to focus only on shareholder's interest (value maximization) but to pursue, as well, the social welfare.

As Bakshi (2007) describes the SRI is growing rapidly. In 1984 the total assets involved in social investing in the United States of America was $\$ 40$ billion. By 1995, this was increased to $\$ 639$ billion. After this year SRI funds kept on growing, in fact they have grown $40 \%$ faster than the total investment market. In 2003 there was a total of $\$ 2.3$ trillion SRI assets in the US, from which \$2 trillion was based on negative screening (avoiding companies with poor environmental and social performance) (Renneboog et al., 2008). Positive screening is also a widely used method to select companies with a good record concerning energy usage or community involvement. This is often combined with a 'best in class' approach, where firms are ranked based on CSR criteria. Negative and positive screens are referred to as the first and second generation of SRI screens (Renneboog et al., 2008).

Renneboog et al. (2008) mention that the most important question regarding the SRI movement: is a firm's aim to maximize shareholder value or social value? The maximization of shareholder value does conflict (most of the time) with the social welfare criterion. By maximizing shareholder value, firms are not taking care of the interest of their other stakeholders. If a firm maximizes shareholder value it needs to be low in costs, therefore stakeholders like employees and suppliers will suffer from these cuts. But can a company survive when it focuses on all its stakeholders? A firm lowering its profits to pursue social and environmental goals may not survive the competition. Another company could acquire this firm and replace the management with a value-maximizing one (Tirole, 2001).

In 2010, professionally managed assets following SRI based strategies had a total value of $\$ 3.07$ trillion, which was an increase of more than 380\% since 1995 (\$639 billion). During the financial crisis, from 2007 till 2010, SRI assets showed healthy growth while the overall size of professionally managed assets remained somewhat flat (Hoon et al., 2013). In the short term the financial performance of SRI funds is no different from conventional investments. But in the long run SRI funds are likely to be superior. As Hoon et al. (2013) states: "companies taking a lead in CSR will gain a competitive advantage and likely outperform their peers".

\subsection{The Impact of Corporate Social Responsible and Corporate Sustainable Strategies on the Long-Term Competitive Advantage and Value Creation}

Lopez et al. (2007) report on the fact that society has begun to demand a change in companies' behavior toward sustainable development. Sustainability philosophy suggests that we should forget the narrow version of classical economic theory and focus on a wider group of stakeholders. Friedman (1970) argues that, according to the classic economic theory, a company's only social responsibility is the maximization of its economic value. From this point of view, any social act is associated with costs that would reduce profit, and therefore it would prejudice shareholders. From the sustainability philosophy point of view we should develop corporate strategies which are not only focused on shareholders' interest, but on the demands of a wider group of stakeholders (Lopez et al., 2007).

In the short term firms are only able to use existing resources to apply sustainable practices, since the time frame is not enough for obtaining supplementary financing. In the long run, resources needed to carry out CSR strategies can be financed. If the changes remain over time, they may create a differentiation which results in long-term competitive advantages (Gladwin et al., 1995). An important factor for companies to choose a social responsible strategy is the economic conditions of that company (Campbell, 2007). Weak corporate financial performance reduces the probability of a company to adopt a corporate sustainable strategy, whereas the level of 
competition increases this responsible behavior (Campbell, 2007).

Indexes linked to financial markets have emerged because of the importance of sustainability practices for investors' investment portfolios. The basic idea of these indexes (such as the DJSWI) is that sustainability practices contribute to long-term value creation. These practices support the development of opportunities and manage economic, environmental and social risks (Lopez et al., 2007). To be included to sustainability indexes, firms are required to disclose information that reflects their sustainability practices (which usually appear in their sustainability reports).

Consolandi et al. (2009) refer to two different views regarding the financial performance of companies aiming to enhance their sustainable performance, the skeptical and the positive view. The skeptical view states that the focus on corporate social responsibility would increase costs and therefore, it would reduce financial performance. On the contrary, the positive view states that the standards of corporate social responsibility reached by a firm can be seen as a sign of good management, a management that is able to mediate the interest of different stakeholder groups in a long-term perspective. According to the positive view the evaluation of corporate social responsible performance could be considered a useful criterion for asset allocation. Excellent corporate social responsible standards would, therefore, increase demand of a stock because of the company's focus on long term firm value. Because of this increasing demand of stock caused by higher corporate social responsible standards managers are incentivized to further strengthen its social responsible standards. Consolandi (2009) states that this virtuous circle has a positive effect on the sustainability of firms and of the entire economy. Therefore, companies should focus more and more on non-financial aspects of corporate performance.

A good example of a period when there was a strong short-term focus were the years before the financial crisis. Bank managers were focused on selling mortgages to every US citizen to increase their (short term) bonuses. As stated before, it was during the financial crisis that SRI assets showed healthy growth while the overall size of professionally managed assets remained somewhat flat (Hoon et al., 2013).

\subsection{Theories Supporting Corporate Sustainability}

The resource-based view sees expenditures which are focused on the environment or socially desirable business practices as investments that increase the reputation of the company and therefore, lead to higher long-run profits. This theory states that corporate sustainability contributes to the reputation of the company and can, consequently, be regarded as a profitable management practice (Lopatta et al., 2013). Maurer et al. (2010) describe resource-based view as something that may create or destroy value. When firms set a strategy that becomes associated with a social issue this creates a risk for the firm, as it may have a positive or a negative effect because the social issue expands the reach of the firm; when this is done properly it will be rewarded by society, but if it is done incorrectly society will punish the company. Nevertheless, the firms that recognize the interplay between their resources and their environmental/social context are able to engage in cultural work and, thereby, preserve their strategy's economic value.

From a legitimacy theory point of view, corporate sustainability can be regarded as an intention of the management to ensure a going concern (Lopatta et al., 2013). It increases the life expectancy of the firm and hence, increases the future cash flows, which enhance firm value. Legitimacy theory can be described as a generalized perception that the actions of an entity are desirable within the socially constructed norms and beliefs (Suchman, 1995). If the behavior of the firm is not according these socially constructed norms and beliefs it is possible that customers or suppliers refuse to do business with this company. Then, the company lacks legitimacy, which can result in a decline in profit or even bankruptcy (Hybels, 1995). In other words a company's performance is legitimate when it is judged to be fair and worthy of support, e.g. when it is socially accepted (Eugenio et al., 2013). But when society is not convinced that the company is operating in a legitimate manner, a legitimacy gap can arise. A legitimacy gap exists when there is a difference in a corporation's actions and the society's beliefs of what these actions should be (O'Donovan, 2002). In other words, a legitimacy gap is the difference between the societal expectations and the perceptions of business behavior. In order to improve its legitimacy within the society, a company should minimize this legitimacy gap by investigating it in the light of its own definitions of "what ought to be" and "what is" appropriate behavior (Panwar et al., 2014).

Stakeholder theory has been developed over the last thirty years as a response to the dominant mindset where corporations are seen as the property of their owners (e.g. shareholders in public corporations). If stakeholder theory is stripped down to its essentials it emerges out of four ideas: the separation fallacy, the open question argument, the integration thesis, and the responsibility principle (Freeman et al., 2010). The separation fallacy states that business and ethical decisions can be regarded as separate decisions. However, there are implications of rejecting the separation fallacy, as almost any business decision has some ethical content. The open question 
argument is based on asking the questions "if a business decision is being made what value is created and destroyed?" and "who is harmed and who does benefit from this decision?" But, an answer could be "only value to shareholders count". Thus, the integration thesis is needed as a theory, where it is stated that most business and ethical decisions are intertwined. And, finally, the responsibility principle states that most people want to accept responsibility for the effects of their actions on others (Freeman et al., 2010). It is clear to see that stakeholder theory is a mix of the integration thesis and the responsibility principle. Stakeholder theory implies that the interest of these groups are joint and that to create value, companies must focus on how value gets created for every stakeholder. Godfrey (2005) used stakeholder theory to describe how corporate sustainability can create shareholder value by creating and maintaining positive stakeholders surrounding the company. These positive stakeholders can serve as a protection for the company's relationship intangible assets. Because the company is aware of this positive relationship and, as a result, is able to reduce its exposure to stakeholder risk (loss of customers, loss of suppliers) it can set a lower cost of capital and hence, (ceteris paribus) higher firm value.

\section{Hypotheses Development}

Lopez et al. (2007) mentioned that a company can demonstrate to investors its focus on long term performance by adopting corporate sustainability principles. The DJSI is a widely used index for investors to distinguish the sustainable companies from the others. Lopatta et al. (2013) also indicated a positive shift of investors towards the companies that incorporated corporate sustainability after the financial crisis in 2008. Moreover, Hoon et al. (2013) reported a significant growth of investments in sustainable companies after the financial crisis considering the overall size of professionally managed assets. Thus, it can be assumed that because of the financial crisis investors opt in favor of long-term oriented, healthy and sustainable companies. Since the DJSI is a widely accepted indicator of sustainable companies, a shift in abnormal returns is expected when a company is included on the DJSI after the financial crisis compared to before.

Cheung (2011) investigated a sample of US stocks which are included in or excluded from the DJSI over the period 2002-2008, and he concluded that the announcement of inclusion has no significant impact on stock return. However, he found a significant but temporary increase (decrease) on stock return when a company was included in (excluded from) the DJSI. Lopez et al. (2007) concluded that sustainability practices contribute to the value creation of the company on the long-term, which in turn should be reflected in the company's share price. Therefore, the inclusion of a company on the DJSI should indicate an increase in sustainability practices and therefore it should result in a higher share price $(H 1)$. On the contrary, the exclusion of a company from the DJSI should indicate a decrease in sustainability practices and therefore should result in a decrease of the share prices (H2). Robinson et al. (2011) explored the change in share prices caused by the inclusion or exclusion from the DJSI during the years 2003-2007 and they found that the mean cumulative abnormal returns for companies included in the DJSI are positive and significant at $2.1 \%$. However, they discovered that companies excluded from the DJSI have a positive but insignificant mean cumulative abnormal return. Therefore, hypotheses 1, 2 and 3 are:

H1: The inclusion of a company on the Dow Jones Sustainability Index has a positive effect on its share price. The Cumulative Abnormal Returns (CAR) are higher than zero when the company is added on the DJSI.

H2: The exclusion of a company on the Dow Jones Sustainability Index has a negative effect on the share price of a company. The Cumulative Abnormal Returns (CAR) are lower than zero when the company is deleted from the DJSI.

H3: There a significant positive difference between the included and excluded companies regarding the abnormal returns.

Lopatta et al. (2013) concluded that during the period 2003-2007 the more sustainable companies experienced a negative effect on their share prices, but the contrary was found for the examined period after the financial crisis. They supported that sustainability is relevant to firm valuation and therefore, it should result in a change in share price when companies' sustainability practices are changed. Hoon et al. (2013) claimed that investors tend to move towards companies with corporate sustainability practices based on the findings of the Social Investment Forum Foundation (2011) that during the financial crisis the overall size of professionally managed assets remained somewhat the same, but social responsible investments assets showed a steady growth. Therefore, hypotheses 4 and 5 are:

H4: There are higher abnormal returns (when a company is added) during the two years after the emergence of the financial crisis (in 2008) compared to the two years before the financial crisis.

H5: There are lower abnormal returns (when a company is deleted) during the two years after the emergence of 
the financial crisis (in 2008) compared to the two years before the financial crisis.

Lopatta et al. (2013) argued that the financial crisis increased the positive perception of corporate sustainability, especially in industries that are exposed to higher environmental and social risks. Waddock et al. (1997) investigated the link between the corporate social performance and financial performance in a wide range of industries and they found significant differences among industries. Therefore, significant differences are expected in the abnormal returns among the different industries included in the DJSI. Thus, hypothesis 6 is:

H6: There is a significant difference in abnormal returns between the different industries.

\section{Research Methodology}

\subsection{Research Model}

In order to investigate if the market responds to the inclusion and/or exclusion of a company from the DJSI, the CAPM-model is employed to test if the actual returns are different from the expected returns. Initially, One-Sample T-test is used to identify if the actual returns are significantly different than the expected returns for both groups of companies (i.e. included in or excluded from the DJSI) for three different periods: 2006-2010 (whole period); 2006-2007 (before the crisis); 2009-2010 (after the crisis). Then, Regression 1 investigates if the cumulative abnormal returns $(\mathrm{CAR})$ of the included companies (dummy variable $=1$ ) are significantly higher than those of the excluded companies (dummy variable $=0$ ) for the aforementioned three periods.

$$
\text { Regression 1: } \mathrm{CAR}=\alpha+\beta_{1} \text { Included Company }+\varepsilon
$$

Regression 2 tests if there is a significant difference in the returns (CAR) of the included companies among different industries for the aforementioned three periods. Every industry has a dummy variable which equals 1 if the company is listed in that particular industry, and 0 otherwise. The dummy variable of the industry Banks is omitted in order to avoid the dummy variable trap (perfect multicollinearity).

$$
\text { Regression 2: } \mathrm{CAR}=\alpha+\beta_{1} \text { Included Company }+\beta_{2} \text { Industry }+\varepsilon
$$

Regression 3 examines if there is a significant difference between the abnormal returns (CAR) two years before the credit-crisis (2006-2007; dummy variable $=0$ ) and two years after (2009-2010; dummy variable $=1$ ) regarding the included companies.

$$
\text { Regression 3: CAR (Included companies) }=\alpha+\beta_{1} \text { After Crisis }+\varepsilon
$$

Regression 4 explores if there is a significant difference between the abnormal returns (CAR) two years before the credit-crisis (2006-2007) and two years after (2009-2010) regarding the excluded companies.

$$
\text { Regression 4: CAR (Excluded companies) }=\alpha+\beta_{1} \text { After Crisis }+\varepsilon
$$

It should be mentioned that, in line with Cheung (2011), none test is performed for any control variables because most of the information (regarding corporate sustainability) is included in the information from the DJSI and because the CAPM-model corrects the stock index overall fluctuations.

\subsection{Sample Selection}

The sample period is from 2005 to 2010, where 2005 is used to detect which companies were deleted in 2006. The information about the companies included in or excluded from the DJSI were obtained from RobecoSAM (Zurich). The initial sample consists of 103 companies included in and 74 companies excluded from the DJSI and after filtering, the final sample comprises 86 companies included in and 43 excluded from the DJSI. For every company there were 2 different 'windows', the estimation window and the event window. The estimation window consists of 205 trading days $(t=-250$ (before the announcement) to $t=-45$ ) and the event window consists of $75(\mathrm{t}=-15$ till $\mathrm{t}=60$ (after the announcement)) trading days. The 15 days before the announcement date detects the existence of an anticipation effect before the announcement. The extreme values were not deleted, thus, every change in share prices during the examined period is incorporated in the data analyzed. Since the DJSI tracks only the 2,500 largest companies in the Dow Jones Global Total Stock Market Index that lead the field in terms of sustainability (Hoon et al., 2013), it was not necessary to select companies based on their market value, number of shares outstanding, number of employees or any other measurement. Every event when a company was included in or excluded from the DJSI was, therefore, considered in the analyses.

After determining the companies included in the sample, their share prices were obtained by DataStream in order to calculate the daily returns and subsequently, the cumulative abnormal returns. The necessary market returns $\left(R_{m}\right)$ and risk free rates $\left(R_{f}\right)$ to estimate the abnormal returns were acquired from the S\&P 500 and the U.S. Department of the Treasury (the daily treasury yield curves with a fixed maturity of 3 months), respectively.

DataStream provided the companies' Total Return Index, which was transformed in daily returns. 


$$
R_{i, t}=\left(R_{a, t+1}-R_{a, t}\right) / R_{a, t}
$$

Where, $R_{i, t}$ are the daily returns, $R_{a, t+1}$ the stock price on day $\mathrm{t}+1$ and $R_{a, t}$ the stock price on day $\mathrm{t}$.

Next, the necessary alpha and the beta coefficients of the CAPM-model for each company (during the estimation window) were estimated by the following linear regression:

$$
R_{i, t}-R_{f}=\alpha+\beta *\left(R_{m}-R_{f}\right)+\varepsilon
$$

Subsequently, the expected returns for each company (during the event window) were calculated by the CAPM-model.

$$
\left(\mathrm{E}\left(R_{i}\right)\right)=\alpha+\beta *\left(R_{m}-R_{f}\right)+R_{f}
$$

Finally, the abnormal return $\left(A R_{i}\right)$ and cumulative abnormal returns $\left(C A R_{i}\right)$ were computed.

$$
\begin{aligned}
& A R_{i}=\left(\mathrm{E}\left(R_{i}\right)\right)-R_{i} \\
& C A R_{i}=\Sigma_{t-15}^{t 60} A R_{i}
\end{aligned}
$$

Table 1 presents the descriptive statistics of actual returns and the cumulative abnormal returns (CAR) of both groups of companies analyzed; included in or excluded from DJSI. The actual returns of the included companies during the period 2006-2010 has a mean of $2.1 \%$ and an abnormal return of $0.7 \%$. This means that during the event window the added companies did have $0.7 \%$ higher returns than expected. The actual return of the added companies two years before the credit-crisis (2006-2007) has a mean of 5.5\% and an abnormal return of $0.4 \%$ which indicates that the added companies had a lower actual return during the event window (2006-2007) compared to the expected returns. On the contrary, the abnormal returns of the added companies two years after the credit-crisis is $8.1 \%$ (with an actual return of $17.5 \%$ ).

During the period 2006-2010 the average abnormal return of the companies excluded from the DJSI is $-1.3 \%$. Whereas the two years before the crisis show a positive average abnormal return of $0.8 \%$, and the two years after the crisis also show a positive average abnormal return of $1.3 \%$.

Table 1. Descriptive statistics of actual returns and cumulative abnormal returns CAR sample of companies

\begin{tabular}{lccccc}
\hline & Minimum & Maximum & Mean & Std. Dev. & No of firms \\
\hline Companies included in the DJSI & & & & & \\
\hline Actual 2006-2010 & -87.487 & 47.457 & 2.114 & 26.048 & 86 \\
CAR 2006-2010 & -65.135 & 29.033 & 0.676 & 16.482 & 86 \\
Actual 2006-2007 & -17.851 & 30.081 & 5.492 & 11.167 & 35 \\
CAR 2006-2007 & -21.714 & 25.576 & -0.393 & 11.411 & 35 \\
Actual 2009-2010 & -6.737 & 47.457 & 17.534 & 12.061 & 36 \\
CAR 2009-2010 & -26.918 & 29.033 & 8.106 & 11.393 & 36 \\
\hline Companies excluded from the DJSI & & & & 43 \\
\hline Actual 2006-2010 & -91.070 & 55.378 & 0.520 & 25.191 & 43 \\
CAR 2006-2010 & -33.235 & 46.203 & -1.335 & 14.595 & 13 \\
Actual 2006-2007 & -29.171 & 18.224 & 5.968 & 12.852 & 13 \\
CAR 2006-2007 & -30.863 & 14.986 & 0.814 & 11.932 & 23 \\
Actual 2009-2010 & -9.836 & 55.378 & 10.816 & 14.895 & 23 \\
CAR 2009-2010 & -23.032 & 46.203 & 1.262 & 15.001 & \\
\hline
\end{tabular}

\section{Research Results}

\subsection{Results for $\mathrm{H} 1, \mathrm{H} 2$ and $\mathrm{H3}$}

$H 1$ and $H 2$ hypotheses were examined by conducting One-Sample T-test analyses for companies included in and excluded from the DJSI, respectively (Table 2). The abnormal returns of the 86 included companies during the whole period (2006-2010) were not found to be significantly different from zero (t-value $=0.380$ ), with a mean of 0.676 and a standard deviation of 16.482. The abnormal returns of the 35 included companies during the period 2006-2007 were also not significantly different from zero ( $\mathrm{t}$-value $=-0.204$ ), but with a negative mean of - 0.393 and standard deviation was 11.411. On the contrary, abnormal returns of the 36 included companies during the period after the financial crisis (2009-2010) are significantly (at 99\% level) different from zero (t-value $=4.269$ ), with a mean of 8.1 and a standard deviation of 11.4. These results are in line with those of Lopatta et al. (2013) who found a shift in abnormal returns after the financial crisis, which indicates that the 
financial crisis could have triggered the focus of investors towards the corporate sustainable companies. Cheung (2011) did not find a significant increase in stock returns (only on the announcement date a temporary increase was found) when companies were included in the DJSI during the period 2002-2008, also in agreement with our results.

Table 2. One-sample T-test results for included and excluded companies

\begin{tabular}{lccc}
\hline & $2006-2010$ & $2006-2007$ & $2009-2010$ \\
\hline Included companies & & & \\
\hline T-value & 0.380 & -0.204 & 4.269 \\
Sig. (2-tailed) & 0.705 & 0.840 & 0.000 \\
Mean & 0.676 & -0.393 & 8.106 \\
Standard deviation & 16.482 & 11.411 & 11.393 \\
$\mathrm{~N}$ & 86 & 35 & 36 \\
\hline Excluded companies & & & 0.404 \\
\hline T-value & -0.600 & 0.246 & 0.690 \\
Sig. (2-tailed) & 0.552 & 0.810 & 1.262 \\
Mean & -1.335 & 0.814 & 15 \\
Standard deviation & 14.594 & 11.932 & 23 \\
$\mathrm{~N}$ & 43 & 13 & \\
\hline
\end{tabular}

Note. $\mathrm{N}$ is the number of included and excluded companies in that specific time period.

According to Table 2, the abnormal returns of the 43 excluded companies (H2) during the 2006-2010 period are not significantly different from zero $(\mathrm{t}$-value $=-0.6)$, with a mean of -1.335 and a standard deviation of 14.594 . However, the abnormal returns of the excluded companies during both periods of 2006-2007 ( N=13) and 2009-2010 $(\mathrm{N}=23)$ have a positive mean of 0.814 and 1.262 , respectively, while $\mathrm{t}$ value is 0.246 and 0.404 , respectively. Robinson et al. (2011) found that the mean cumulative abnormal returns for companies included in the DJSI are positive and significant at 2.1\% during the period 2002-2007), while the companies excluded from the DJSI have a positive but insignificant mean of cumulative abnormal return. Consequently, our results coincide with those of Robinson et al. (2011) and they indicate that the inclusion of a company in the DJSI has more influence on its share price than its exclusion from the DJSI.

With respect to $H 3$, the Regression 1 results (Table 3 ) denote that there is a positive, but insignificant, difference in the abnormal returns of the included companies compared with the excluded companies during the period 2006-2010. On the contrary, a negative, but again insignificant, difference is found in the abnormal returns of the included companies compared with the excluded companies during the period 2006-2007. However, it is observed that the included companies have a significantly higher abnormal return than the excluded companies during the examined period after the financial crisis (2009-2010) and in particular, on average, the included companies have a $6.844 \%$ higher abnormal returns than the excluded companies. These results are consistent with those of Lopatta et al. (2013) who revealed that after the height of the financial crisis (September, 2008 when Lehman Brothers filed for bankruptcy protection) the previously negative perception of corporate sustainability was outplaced by a positive stance.

Table 3. Regression 1 results for 2006-2010, 2006-2007 and 2009-2010 periods

\begin{tabular}{lcccc}
\hline & & CAR $(2006-2010)$ & CAR $(2006-2007)$ & CAR $(2009-2010)$ \\
\hline Included companies & B & 2.011 & -1.207 & 6.844 \\
& Std. Error & $(2.966)$ & $(3.751)$ & $(3.445)$ \\
& $\mathrm{t}$ & 0.678 & -0.322 & 1.987 \\
Constant & Sig. & 0.499 & 0.749 & 0.052 \\
& $\mathrm{~B}$ & -1.355 & 0.814 & 1.262 \\
& Std. Error & $(2.422)$ & $(3.203)$ & $(2.691)$ \\
$\mathrm{N}$ & $\mathrm{t}$ & -0.551 & 0.254 & 0.469 \\
$R^{2}$ & Sig. & 0.582 & 0.801 & 0.641 \\
Adjusted $R^{2}$ & & 129 & 48 & 59 \\
\hline
\end{tabular}

Note. $\mathrm{N}$ is the total number of included and excluded companies during that specific time period. 
Therefore, it can be concluded that the financial crisis provoked a positive shift in investors' attitudes towards corporate sustainable companies. Van de Ven et al. (2011) support that companies should consider the claims of all their stakeholders in proportion and not merely focus on the shareholders' value maximization, and they should also be more transparent and long-term oriented. Hence, companies should endorse the corporate social responsible and corporate sustainable strategies in order to create and maintain long-term competitive advantage.

\subsection{Results for $\mathrm{H} 4$ and $\mathrm{H} 5$}

The results from Regression 3 (Table 4) indicate that Hypothesis 3 is supported, as with a t-value of 3.140 and a significance level of $99.8 \%$ it is evident the abnormal returns of the included companies after the financial crisis are significantly higher than the abnormal returns of the included companies before the financial crisis. On the contrary, based on the results from Regression 4 (Table 4) it is found Hypothesis 4 is not supported since the $\mathrm{t}$-value of 0.092 , thus, the cumulative abnormal returns of the excluded companies after the financial crisis have not decreased significantly compared to the two years before the financial crisis. Therefore, in line with Lopatta et al. (2013) it can be claimed that the market (i.e. the investors) value the inclusion of a company on the DJSI more after the financial crisis than before the financial crisis. In contrast, the exclusion of a company from the DJSI has not a significant different impact on share prices after the financial crisis than before the financial crisis.

Table 4. Results of regression 3 and Regression 4

\begin{tabular}{lccccc}
\hline (Regression 3) & & & & \\
\hline Included companies & $\mathrm{B}$ & 8.499 & Excluded companies & $\mathrm{B}$ & 0.448 \\
& Std. Error & $(2.707)$ & & Std. Error & $(4.856)$ \\
& $\mathrm{t}$ & 3.140 & & $\mathrm{t}$ & 0.092 \\
& $\mathrm{Sig}$ & 0.002 & & Sig. & 0.927 \\
Constant & $\mathrm{B}$ & -0.393 & Constant & $\mathrm{B}$ & 0.814 \\
& Std. Error & $(1.927)$ & & Std. Error & $(3.881)$ \\
& $\mathrm{t}$ & -0.204 & & $\mathrm{t}$ & 0.210 \\
$\mathrm{~N}$ & Sig. & 0.839 & & Sig. & .0835 \\
$R^{2}$ & & 71 & $\mathrm{~N}$ & & 36 \\
Adjusted $R^{2}$ & & 0.125 & $R^{2}$ & & 0 \\
\hline
\end{tabular}

\subsection{Results for $\mathrm{H6}$}

Lastly, it is investigated if investors react differently to the inclusion or exclusion of a company according to the industry it belongs. The results from Regression 2 (Table 5) reveal that Hypothesis 6 is not supported, since there is no significant difference (apart from Chemicals during 2006-2010) in the cumulative abnormal returns among the different industries. However, the differentiation of our research results from prior research (Lopatta et al., 2013; Waddock et al., 1997) may, amongst others, be attributed to the small sample for each individual industry. Therefore, analyzing data from a longer time period could provide sufficient evidence to draw firm conclusions.

Table 5. Regression 2 results for 2006-2010, 2006-2007 and 2009-2010 periods

\begin{tabular}{lccc}
\hline Different Industries & CAR $(2006-2010)$ & CAR $(2006-2007)$ & CAR $(2009-2010)$ \\
\hline Included companies & 2.284 & 2.390 & 5.382 \\
& $(3.108)$ & $(5.013)$ & $(3.820)$ \\
Basic Resources & 2.190 & 0.637 & 14.033 \\
& $(8.748)$ & $(9.304)$ & $(11.846)$ \\
Chemicals & $-17.336^{*}$ & 7.589 & -10.688 \\
& $(9.144)$ & $(10.159)$ & $(13.088)$ \\
Construction Materials & -8.121 & & 2.161 \\
& $(12.859)$ & & $(11.888)$ \\
Financial Services & 1.878 & -13.412 & 1.757 \\
& $(9.144)$ & $(10.464)$ & $(13.088)$ \\
\hline
\end{tabular}




\begin{tabular}{|c|c|c|c|}
\hline Health Care & $\begin{array}{c}7.931 \\
(7.646)\end{array}$ & $\begin{array}{c}6.501 \\
(7.431)\end{array}$ & $\begin{array}{c}7.379 \\
(10.608)\end{array}$ \\
\hline Industrial Goods \& Services & $\begin{array}{l}-3.813 \\
(7.974)\end{array}$ & $\begin{array}{l}-6.201 \\
(9.304)\end{array}$ & $\begin{array}{c}-0.408 \\
(10.734)\end{array}$ \\
\hline Insurance & $\begin{array}{l}-9.817 \\
(8.835)\end{array}$ & $\begin{array}{l}-2.125 \\
(8.666)\end{array}$ & $\begin{array}{l}-15.572 \\
(13.088)\end{array}$ \\
\hline Media & $\begin{array}{c}5.677 \\
(9.085)\end{array}$ & $\begin{array}{c}6.479 \\
(9.304)\end{array}$ & $\begin{array}{c}8.525 \\
(13.088)\end{array}$ \\
\hline Oil and Gas & $\begin{array}{c}4.125 \\
(8.408)\end{array}$ & $\begin{array}{l}-17.631 \\
(13.353)\end{array}$ & $\begin{array}{c}7.184 \\
(10.734)\end{array}$ \\
\hline Personal and Household Goods & $\begin{array}{c}-5.651 \\
(11.175)\end{array}$ & $\begin{array}{c}3.357 \\
(13.353)\end{array}$ & $\begin{array}{c}-7.944 \\
(16.311)\end{array}$ \\
\hline Real Estate & $\begin{array}{c}-3.125 \\
(11.175)\end{array}$ & & $\begin{array}{c}-5.119 \\
(15.858)\end{array}$ \\
\hline Retail & $\begin{array}{c}-0.484 \\
(7.714)\end{array}$ & $\begin{array}{l}-6.089 \\
(7.362)\end{array}$ & $\begin{array}{c}4.830 \\
(10.743)\end{array}$ \\
\hline Technology & $\begin{array}{l}-4.634 \\
(7.739)\end{array}$ & $\begin{array}{l}-1.742 \\
(8.666)\end{array}$ & $\begin{array}{c}-0.018 \\
(10.874)\end{array}$ \\
\hline Telecommunications & $\begin{array}{c}0.905 \\
(11.175)\end{array}$ & & $\begin{array}{c}-2.124 \\
(12.091)\end{array}$ \\
\hline Utilities & $\begin{array}{c}1.842 \\
(8.020)\end{array}$ & $\begin{array}{c}3.454 \\
(7.755)\end{array}$ & $\begin{array}{c}-4.580 \\
(11.573)\end{array}$ \\
\hline Constant & $\begin{array}{l}-0.849 \\
(6.507)\end{array}$ & $\begin{array}{l}-1.384 \\
(6.379)\end{array}$ & $\begin{array}{c}0.115 \\
(9.115)\end{array}$ \\
\hline $\mathrm{N}$ & 129 & 48 & 59 \\
\hline$R^{2}$ & 0.145 & 0.002 & 0.306 \\
\hline Adjusted $R^{2}$ & 0.014 & -0.019 & 0.042 \\
\hline
\end{tabular}

Note. *,**, and $* * *$ indicate statistical significance at the 10,5 , and 1 percent levels, respectively.

$\mathrm{N}$ is the total number of included and excluded companies during that specific time period.

\section{Conclusion, Limitations and Recommendations}

The research results demonstrate that after the financial crisis the investors appreciate corporate sustainability more than before the financial crisis. Moreover, after the financial crisis (2009-2010) there is a significant positive abnormal return when a company is included in the DJSI, while during the periods 2006-2010 and 2006-2007 the investors did not value significantly companies' corporate sustainability. Therefore, investors changed their investment strategies in favor of the more corporate sustainable companies (included in the DJSI) compared to unsustainable companies (excluded from the DJSI). These positive abnormal returns are significantly higher compared to the abnormal returns before the financial crisis. On the contrary, the exclusion of a company from the DJSI was not found to have a significant negative impact on the companies' share price in any of the examined periods (2006-2010, 2006-2007, 2009-2010). Thus, investors tend to appreciate positively the inclusion of a company in the DJSI, however it seems that the exclusion of a company from the DJSI matters a little to investors.

The study results are partly consistent with the Resource-based view, as companies get rewarded after increasing their focus on corporate sustainability (when included on the DJSI), especially after the financial crisis. However, companies do not get punished by society when they fail to remain sustainable (when excluded from the DJSI). Therefore, our results do not support the view of Maurer et al. (2010) that describe resource-based view as something that may create or destroy value. From the legitimacy theory point of view, companies need to operate in line with the socially constructed norms and beliefs (Suchman, 1995) if they do not wish to lack legitimacy, which in turn can cause a decline in profit or even bankruptcy (O'Donovan, 2002; Hybels, 1995). However, our analysis revealed that for all the examined periods the companies which are excluded from the DJSI did not realize any decline in profit. Stakeholder theory supports that companies can create shareholder value by creating positive stakeholders which can serve as a protection for the company (Godfrey, 2005). If a company has loyal stakeholders this reduces its stakeholder risk and is, therefore, able to achieve a lower cost of capital, which in turn can increase firm value if everything else stays the same. The research results are in accordance with the stakeholder theory, since a company's inclusion in the DJSI (an indicator of its enhanced stakeholder 
engagement) yields an increase in shareholders' value.

The examined period in this research is 2006-2010, therefore, it would be rather interesting to investigate if the investors' positive stance to corporate sustainability after the emergence of the financial crisis remained the same or was later modified, namely during the period 2010-2015. Moreover, analyzing data from a longer time period could provide sufficient evidence to draw firm conclusions regarding the potential differences in investors' reaction to the inclusion or exclusion of a company from the DJSI according to the industry it belongs.

\section{References}

Adams, C., \& Zutshi, A. (2004). Corporate Social Responsibility: Why business should act responsibly and be $\begin{array}{lllll}\text { accountable. Australian } & \text { Accounting }\end{array}$ http://dx.doi.org/10.1111/j.1835-2561.2004.tb00238.x

Bakshi, (2007). Transforming markets in the 21st century: Socially responsible investing as a tool. Futures, 39(5), 523-533. http://dx.doi.org/10.1016/j.futures.2006.10.002

Campbell, J. L. (2007). Why would corporations behave in socially responsible ways? An institutional theory of corporate social responsibility. The Academy of Management Review, 32, 946-967. http://dx.doi.org/10.5465/AMR.2007.25275684

Cheung, A. W. K. (2011). Do Stock Investors Value Corporate Sustainability? Evidence from an Event Study. Journal of Business Ethics, 9(2), 145-165. http://dx.doi.org/10.1007/s10551-010-0646-3

Consolandi, C., Jaiswal-Dale, A., Poggiani, E., \& Vercelli, A. (2009). Global standards and ethical stock indexes: The case of the Dow Jones Sustainability Stoxx Index. Journal of Business Ethics, 87, 185-197. http://dx.doi.org/10.1007/s10551-008-9793-1

Eugenio, T. P., Lourenzo, I. C., \& Morais, A. I. (2013). Sustainability strategies of the company TimorL: extending the applicability of legitimacy theory. Management of Environmental Quality: An International Journal, 24, 570-582. http://dx.doi.org/10.1108/MEQ-03-2011-0017

Freeman, R. E., Harrison, J. S., \& Wicks, A. C. (2010). Stakeholder theory: The state of art. Cambridge University Press.

Friedman, M. (1970). The social responsibility of business is to increase its profits. The New York Times Magazine, $32-33,122,126$.

Gladwin, T. N., Kennelly, J. J., \& Krause, T. (1995). Shifting Paradigms for Sustainable Development: Implications for Management Theory and Research. Academy of Management Review, 20, 874-907. http://dx.doi.org/10.5465/AMR.1995.9512280024

Godfrey, P. C. (2005). The relationship between corporate philanthropy and shareholder wealth: A risk management perspective. Academy of Management Review, 30, 777-798. http://dx.doi.org/10.5465/AMR.2005.18378878

Hoon Oh, C., Park, J. H., \& Ghauri, P. N. (2013). Doing right, investing right: Socially responsible investing and shareholder activism in the financial sector. Business Horizons. 56, 703-714. http://dx.doi.org/10.1016/j.bushor.2013.07.006

Hybels, R. C. (1995). On legitimacy, legitimation, and organizations: A critical review and integrative theoretical model. Academy of Management Best Papers Proceedings, 241-245.

Kolk, A. (2010). Trajectories of sustainability reporting by MNCs. Journal World of Business, 45, 367-374. http://dx.doi.org/10.1016/j.jwb.2009.08.001

Lopatta, K., \& Kaspereit, T. (2013). The world capital markets' perception of sustainability and the impact of the financial crisis. Journal of Business Ethics, 122, 475-500.

Lopez, M. V., Garcia, A., \& Rodriquez, L. (2007). Sustainable Development and Corporate Performance: A Study Based on the Dow Jones Sustainability Index. Journal of Business Ethics, 75, 285-300. http://dx.doi.org/10.1007/s10551-006-9253-8

Maurer, C. C., Bansal, P., \& Crossan, M. M. (2010). Creating economic value through social values: Introducing a culturally informed resource-based view. Organizational Science, 22, 432-448. http://dx.doi.org/10.1287/orsc.1100.0546

O'Donovan, G. (2002). Environmental disclosures in the annual report: Extending the applicability and predictive power of legitimacy theory. Accounting, Auditing and Accountability Journal, 15, 344-371. 
http://dx.doi.org/10.1108/09513570210435870

Panwar, R., Hansen, E., \& Kozak, R. (2014). Evaluating social and environmental issues by integrating the legitimacy gap with expectational gaps: An empirical assessment of the forest industry. Business \& Society, 53, 853-875. http://dx.doi.org/10.1177/0007650312438884

Renneboog, L., Ter Horst, J., \& Zhang, C. (2008). Socially responsible investments: Institutional aspects, performance, and investor behavior. Journal of Banking \& Finance, 1723-1742. http://dx.doi.org/10.1016/j.jbankfin.2007.12.039

Robeco SAM. (2014). Corporate Sustainability Assessment. Annual Scoring \& Methodology Review.

Robinson, M., Kleffner, A., \& Bertels, S. (2011). Signaling sustainability leadership: Empirical evidence of the value of DJSI membership. Journal of Business Ethics, 101, 493-505. http://dx.doi.org/10.1007/s10551-011-0735-y

Searcy, C., \& Elkhawas, D. (2012). Corporate sustainability ratings: An investigation into how corporations use the Dow Jones Sustainability Index. Journal of Cleaner Production, 35, 79-92. http://dx.doi.org/10.1016/j.jclepro.2012.05.022

Suchman, M. C. (1995). Managing legitimacy strategic and institutional approaches. Academy of Management Review, 20, 571-610. http://dx.doi.org/10.5465/AMR.1995.9508080331

Tirole, J. (2001). Corporate governance. Econometrica, 69, 1-35. http://dx.doi.org/10.1111/1468-0262.00177

Van de Ven, B. W., \& Graafland, J. J. (2011). The credit crisis and the moral responsibility of professionals in finance. Journal of Business Ethics, 103, 605-619. http://dx.doi.org/10.1007/s10551-011-0883-0

Waddock, S. A., \& Graves, S. B. (1997). The corporate social performance-financial performance link. Strategic Management Journal, 303-319. http://dx.doi.org/10.1002/(SICI)1097-0266(199704)18:4<303::AID-SMJ869>3.0.CO;2-G

World Business Council for Sustainable Development (WBCSD). (2002). Sustainable Development Reporting: Striking the Balance World Business Council for Sustainable Development, Geneva (2002).

\section{Copyrights}

Copyright for this article is retained by the author(s), with first publication rights granted to the journal.

This is an open-access article distributed under the terms and conditions of the Creative Commons Attribution license (http://creativecommons.org/licenses/by/3.0/). 